\title{
IF YOU DON'T USE IT, YOU LOSE IT: WHAT THE U.S. COULD LEARN FROM FRANCE'S LAW ON OUT-OF-COMMERCE BOOKS OF THE 20 $^{\text {TH }}$ CENTURY
}

\author{
FRANCIS X. MATTINGLY*
}

\section{INTRODUCTION}

The foundation of copyright law is that the authority to use or otherwise exploit copyrighted material is solely under the control of the rights holder. ${ }^{1}$ As such, third parties wishing to make use of copyrighted materials must first ask the permission of the rights holder before undertaking any exploitation of that work. ${ }^{2}$ While rights holders are generally allowed to ignore any such requests, potential users of works have found their ability to seek permission to use a work or to negotiate licensing terms with the rights holder compromised when that rights holder cannot be located even through the diligent efforts of the user. ${ }^{3}$ This is essentially the definition of an "orphan work."

Recent technological advances have made possible the mass digitization of a large quantity of works. This has allowed certain works to become orphaned very quickly, as these works can now be uploaded and disseminated easily without proper permission or credit given to the rights holder. ${ }^{5}$ This can potentially affect a wide range of users including commercial entities wishing to reissue books long since out of print, libraries and archives attempting to preserve certain works that may be forgotten or practically unavailable, and even individuals trying to make use of content found on the Internet. ${ }^{6}$ In response to these increasingly pervasive issues, countries across the globe have begun adopting legislation relating to orphan works and mass digitization. ${ }^{7}$ Attempted solutions have ranged from providing exceptions for certain uses to extended collective licensing ("ECL"), whether carried out by the government or private entities. $^{8}$

Currently, orphan works constitute a significant part of the literary heritage

* B.A. Indiana University Bloomington, 2014; J.D. Indiana University Robert H. McKinney School of Law, 2017.

1. Bernard Lang, Orphan Works and the Google Book Search Settlement: An International Perspective, 55 N.Y.L. SCH. L. REV. 111, 112 (2010).

2. Id.

3. Register of Copyrights, U.S. Copyright Office, Orphan Works and Mass Digitization, 1 (2015).

4. Kevin J. Hickey, Consent, User Reliance, and Fair Use, 16 YALE J. L. \& TeCH. 397, 439 (2013/2014).

5. Vicenc Feliu, Orphans in Turmoil: How a Legislative Solution Can Help Put the Orphan Works Problem to Rest, 12 Rutgers J.L. \& PuB. POL'Y 107, 108-09 (2015).

6. Id. at 110.

7. Register of Copyrights, supra note 3 , at 2 .

8. Id. 
of not only the United States ("U.S.") but also many countries around the world. ${ }^{9}$ As a result, they present a substantial obstacle to mass digitization projects in that the copyright owners are impossible to track down in order to seek permission. ${ }^{10}$ Thus, orphan works are undermining the preservation of our culture through digitization projects, which could present substantial benefits to every man, woman, and child able to access a computer. ${ }^{11}$ History is replete with examples of potentially important texts that have been lost to history from Homer's comedy epic Margites to the memoirs of Lord Byron. ${ }^{12}$ Time, or the rash decisions of an overly nervous publisher have deprived people today of the opportunity to study or enjoy these and many other texts, and mass digitization is seen as a way to prevent such losses in the future. ${ }^{13}$ Not only does mass digitization of literature help to preserve ancient texts, but it also provides access to works that may be too delicate to handle in their physical form or located too far away for an interested reader to access. For example, Lehigh University is currently heading up a project, known as Bibliotheca Philadelphienis, aimed at digitizing a large collection of medieval texts previously only accessible by visiting Lehigh's Linderman Library in person. ${ }^{14}$ One of the leaders of the project notes that, although the collection is well known by researchers, the project will bring the works to a much wider audience. ${ }^{15}$ According to Lisa Davis, the Executive Director of the Medieval Academy of America, the project is "a great gift to the world." " In short, the mass digitization of literary works is an essential element of preserving our culture, and orphan works will necessarily be included in any projects encompassing the last century or so. A comprehensive copyright regime must include a policy that accomplishes two goals: 1 . Allow any potential rights holder to exercise his or her rights to exploit the copyrighted material; and 2. Provide the public with access to such works within a reasonable time to preserve the academic use or cultural value of the work.

This Note explores various attempts to solve the problems arising out of orphan works and mass digitization, particularly as they relate to literary works and including the policy considerations underlying the choices made by different governments. Section II provides a brief discussion of the origins and causes of the orphan works problem generally, and how this has affected orphaned literary

9. Lang, supra note 1, at 114.

10. Diane Leenheer Zimmerman, Can Our Culture Be Saved? The Future of Digital Archiving, 91 MinN. L. REV. 989, 1025 (2007).

11. Id. at 990 .

12. Paul Anthony Jones, Gone for Good: The Long Lost Works of English Literature, HufFINGTON POST (Feb. 7, 2015), http://www.huffingtonpost.com/paul-anthony-jones/long-lostworks_b_6271482.html.

13. Id.

14. Susan Snyder, Bringing Medieval Works to the Digital World, The Philadelphia ENQUIRER (Feb. 12, 2016), http://www.vnews.com/lifetimes/21004635-95/bringing-medievalworks-to-the-digital-world [https://perma.cc/S8FM-L7BF].

15. Id.

16. Id. 
works. Section III examines how various entities have attempted to combat this problem, including a summary of the Nordic countries' legislative solution (the Nordic ECL model), judicial attempts to solve the problem in the U.S. (the Google Books and HathiTrust cases), the case-by-case approach utilized in Canada, and the European Union's ("EU's") 2012 Orphan Works Directive. Section IV compares and contrasts the U.S. Copyright Office's ("USCO's") 2015 proposed legislation and the considerations behind it with France's Loi 2012-287 and the discussion of the French Constitutional Council in its decision to uphold the law amid challenges from authors and publishers. This Note concludes by recommending that a provision similar to Loi 2012-287 could be implemented in the U.S., which would not only preserve the public policy goals of the USCO but would also provide an efficient means of identifying potential rights holders and making these works available to the public.

\section{THE ORPHAN WORKS PROBLEM AND WORKS OF LITERATURE}

\section{A. Origins and Causes}

The orphan works problem is not a new one. ${ }^{17}$ Despite the existence of a system for copyright registration and renewal, a rights holder's information has the potential of becoming outdated while the work is still under copyright protection. ${ }^{18}$ Under the principles of the Berne Convention, copyright protection must at a minimum extend to fifty years after the author's death. ${ }^{19}$ In the $1990 \mathrm{~s}$, the U.S. and several countries across Europe adopted the Berne Convention, extending copyright protection to seventy years after the author's death. ${ }^{20}$ Immediately, the number of older works that were entitled to copyright protection skyrocketed. ${ }^{21}$ Increased longevity in copyright protection appears to have created more difficulties in locating the correct rights holder for certain works. ${ }^{22}$ Further, changes to copyright laws have eased the obligations of rights holders to assert and manage their rights by eliminating formalities. ${ }^{23}$ Where previously formalities allowed potential users to easily access the rights holders' contact information, their elimination has frustrated users' efforts. ${ }^{24}$ The current "no-formality approach" is also a product of the Berne Convention, which requires all signatory

17. Feliu, supra note 5, at 109.

18. Id.

19. Summary of the Berne Convention for the Protection of Literary and Artistic Works, WIPO (1886), http://www.wipo.int/treaties/en/ip/berne/summary_berne.html [https://perma.cc/A6WK-JTTP].

20. Katharina de la Durantaye, Finding a Home for Orphans: Google Book Search and Orphan Works Law in the United States and Europe, 21 Fordham InTELl. Prop. Media \& EnT. L.J. 229, 239 (2011).

21. Id.

22. Feliu, supra note 5, at 109.

23. Register of Copyrights, supra note 3 , at 10.

24. Id. 
countries to adhere to such a policy. ${ }^{25}$ As a result of the adoption of the Berne Convention, the U.S. now only requires registration of copyrights for those wishing to sue for certain types of damages for copyright infringement. ${ }^{26}$ In fact, registration is only required for those plaintiffs seeking statutory damages or attorney's fees. ${ }^{27}$ The result has been incomplete or inaccurate contact information for those works that are registered ${ }^{28}$ and many works are going unregistered, thereby rendering the copyright registry no longer exhaustive or comprehensive. ${ }^{29}$

However, the Berne Convention's increase in the amount of time a work remains under copyright protection and its elimination of formalities are not the only phenomena that have contributed to the orphan works problem. ${ }^{30}$ Digital technology has facilitated the separation of works or parts of works from the contact information of the rights holders. ${ }^{31}$ Both innocent and bad faith actors have been guilty of causing this separation. ${ }^{32}$ Because of the recent changes in copyright law, copyright protection automatically attaches to works. ${ }^{33}$ Thus, any potential users are forced to assume that any work they access via the Internet is protected, even though the contact information of the rights holder may not be attached to the work. ${ }^{34}$ As a result, potential users of these works will find it difficult to obtain the necessary licenses to use them. ${ }^{35}$ Mass digitization projects, such as Google Books, magnify these difficulties to the extent that the legal uncertainties and costs of identifying rights holders represent a major obstacle to such projects' utility and success. ${ }^{36}$

Business practices have also furthered the publication of copyrighted material without giving proper credit to the copyright holder. ${ }^{37}$ Particularly in the case of advertising, photographs or other copyrighted works are displayed without authorization or credit given to the rights holder. ${ }^{38}$ For example, in Agence France Presse v. Morel, Morel posted pictures that he had taken of the earthquake

25. Bingbin Lu, The Orphan Works Copyright Issue: Suggestions for an International Response, 60 J. COPYRIGHT SOC'Y 255, 258 (2013).

26. Durantaye, supra note 20, at 238.

27. 17 U.S.C. $\S 412$ (Lexis 2015).

28. Register of Copyrights, supra note 3, at 10.

29. Durantaye, supra note 20, at 238.

30. The Orphan Works Problem and Proposed Legislation: Hearing before the Subcomm. on Courts, the Internet, and Intellectual Prop. Of the H. Comm. On the Judiciary, $110^{\text {th }}$ Cong. (2008) (statement of Marybeth Peters, the Register of Copyrights), http://www.copyright.gov/ docs/regstat031308.html. (hereinafter "Peters"). [https://perma.cc/HR7G-3GH5]

31. Durantaye, supra note 20, at 237-38.

32. Id.

33. Lu, supra note 25 , at 257.

34. Id.

35. Id.

36. Id.

37. Durantaye, supra note 20, at 237.

38. Id. 
disaster in Haiti to his Twitter page and within minutes another Twitter user, Lisandro Suero, had copied the pictures and reposted them with a statement that the pictures were his "for credit and copyright." ${ }^{39}$ In the ensuing rush to obtain media coverage of the events, Agence France Presse downloaded the pictures from Suero's page and licensed them to Getty Images, who in turn licensed them to news companies such as $\mathrm{CNN}$ and CBS. ${ }^{40}$ The problem, however, was that the images that eventually ended up on national news reports contained Suero's name in the credit line instead of Morel's, forcing Morel to institute litigation in order to gain his rightful credit on the photographs. ${ }^{41}$ Despite the issues raised by Morel and similar cases, it certainly can, and has been argued that technology, such as Google's search features, allows for easier access to and retrieval of information including publisher and copyright holder information. ${ }^{42}$ Additionally it has been argued that these technological tools will help publishers and authors to make more money from their works than they had previously by allowing potential users to find small snippets of a full text then purchase the full version from the rights holders. ${ }^{43}$ So, while problems such as the one presented in Morel will continue to present themselves, technology can be used to remedy some of the very same problems it causes. Nevertheless, the USCO notes that the most important issue with mass digitization is "not so much the lack of information as it is a lack of efficiency in the licensing marketplace." ${ }^{44}$

\section{B. The Orphan Works Problem and Works of Literature}

The sheer scale of the orphan works problem as it relates to literary works is surprisingly large. ${ }^{45}$ Because books are considered to be central to many cultural collections, they are relevant to the majority of mass digitization projects. ${ }^{46}$ The British Library estimates that 40 percent of their entire collection of copyrighted works is comprised of orphan works. ${ }^{47}$ Likewise, the Danish National Library notes that its collection contains nearly 160,000 works written between the years 1880 and 1930 that may be considered orphaned. ${ }^{48}$ As part of its 2010 initiatives

relating to mass digitization, the European Commission issued a report on the

39. Agence Fr. Presse v. Morel, 769 F. Supp.2d 295, 299 (S.D.N.Y. 2011).

40. Id. at 299-300.

41. Id. at 299.

42. Emily Anne Proskine, Note, Google's Technicolor Dreamcoat: A Copyright Analysis of the Google Book Search Library Project, 21 BERKLEY TECH. L. J. 213, 227 (2006).

43. Kevin Maney, Critics Should Grasp Google Projects Before Blasting Them, USATODAY.COM, (Nov. 5, 2005), http://usatoday30.usatoday.com/money/industries/technology/ maney/2005-11-08-google_x.htm. [https://perma.cc/ZB64-Z6YQ].

44. Register of Copyrights, supra note 3 , at 5 .

45. Lu, supra note 25, at 256.

46. Register of Copyrights, supra note 3, at 85.

47. Lu, supra note 25, at 256.

48. Feliu, supra note 5, at 111. 
assessment of orphan works in the EU. ${ }^{49}$ In that report, the Commission found that over 3,000,000 books in the EU were orphan works. ${ }^{50}$ France has already begun listing so-called "unavailable" titles on a government-run website. ${ }^{51}$ The current list contains well over 100,000 of such titles within France. ${ }^{52}$ While the U.S. has not undertaken a study similar to the scope of the European Commission's or any of those in individual European countries, the orphan works problem in the U.S. has been described as "pervasive." ${ }^{53}$ Furthermore, several universities across the country, including Carnegie Mellon and Cornell, have performed various studies regarding their own collections. ${ }^{54}$ Carnegie Mellon's study, for example, found that nearly one-fourth of the school's book collection was made up of works for which the publisher or rights holder could not be located. ${ }^{55}$ In comments submitted to the USCO, Cornell stated that out of the 343 out-of-print monographs subject to copyright protection that the school wanted to include in its mass digitization project, 198 of them were orphan works. ${ }^{56}$

Although listings such as the one published in France contain large numbers of out-of-commerce and orphaned literary works, rights holders and publishers have apparently been unwilling to exploit their works. ${ }^{57}$ As of October 2013, only 2,500 rights holders in France had objected to collective management of their works and expressed a desire to publish digital editions of such works. ${ }^{58}$ Similarly, Carnegie Mellon's study found that in the case of out-of-commerce books, even rights holders that could be located only responded to requests for permission to use their works about one-third of the time. ${ }^{59}$ Cornell's experience with its mass digitization project revealed other problems arising out of attempts to digitize, or otherwise exploit orphan literary works, including the rights holder's ignorance of the extent of his rights with regard to a work, as well as the cost of attempting to locate and identify rights holders. ${ }^{60}$ In its attempts to resolve

49. Id.

50. Id.

51. Register of Copyrights, supra note 3 at 85.

52. Liste complete de livres en gestion collective, Bibliotheque Nationale de France, https://relire.bnf.fr/registre-gestion-collective.

53. Peters, supra note 30.

54. See Comments on Orphan Works Notice of Inquiry from Denise Troll Covey, Principal Librarian for Special Projects Carnegie Mellon Univ. Libraries, to Jule L. Sigall, Assoc. Register for Policy \& Int'l Affairs, U.S. Copyright Office (Mar. 22, 2005), http://www.copyright. gov/orphan/comments/OW0537-CarnegieMellon.pdf [hereinafter Covey]; see Comments on Orphan Works Notice of Inquiry from Sarah E. Thomas, Cornell's Carl A. Kroch Univ. Librarian to Jule L. Sigall, Assoc. Register for Policy \& Int'l Affairs, U.S. Copyright Office (Mar. 23, 2005), http://www.copyright.gov/orphan/comments/OW0569-Thomas.pdf [hereinafter Thomas].

55. Covey, supra note 54.

56. Thomas, supra note 54.

57. Register of Copyrights, supra note 3, at 26-27.

58. Id. at 27 .

59. Covey, supra note 54.

60. Thomas, supra note 54. 
copyright issues relating to its digitization of copyright protected monographs, Cornell University Library spent nearly $\$ 50,000$ and was still only able to clear less than one-third of its collection for digitization. ${ }^{61}$ The types of issues arising out of the Carnegie Mellon and Cornell projects have hampered many mass digitization projects, particularly in the U.S. ${ }^{62}$ However, despite all of the issues associated with such projects, both the U.S. and the European Commission have touted their utility as a means of preserving cultural heritage, facilitating research and allowing greater and easier access to books. ${ }^{63}$ In its most recent report on orphan works and mass digitization, the USCO stated that in attempting to reconcile these considerations, the main question is whether copyright law can effectively "strike an appropriate balance between facilitating those aspects of mass digitization that serve the public interest and safeguarding the rights of copyright owners." ${ }^{64}$ So far, the answer for the U.S. has been "no." 65

\section{ATtempts to SOlVE THE ORPHAN WORKS PROBLEM AT HOME AND ABROAD}

\section{A. The Nordic Model}

All five Nordic countries (Finland, Iceland, Denmark, Norway, and Sweden) have adopted legislation implementing a system known as extended collective licensing ("ECL"), and each apply the system in almost exactly the same way. ${ }^{66}$ Under the ECL system, groups known as collective management organizations ("CMOs") are granted the authority to issue and manage licenses to works ${ }^{67}$ The management authority given to these organizations can even be exercised over works owned by rights holders who do not actually belong to a CMO. ${ }^{68}$ The successful functioning of the ECL system requires that CMOs be representative of specific categories of authors; and in all of the Nordic countries except Sweden, the government must approve a CMO for its specified task. ${ }^{69}$ Although most of the Nordic ECL systems are only applied to specific types of users, the Danish ECL system can be applied to any type of user. ${ }^{70}$ In Denmark, the system allows CMOs and potential users to negotiate on their own the way specific

61. Id.

62. Register of Copyrights, supra note 3 , at 74.

63. Id. at 73-74.

64. Id. at 75 .

65. Id.

66. Anna Vuopala, Extended Collective Licensing: A Solution for Facilitating Licensing of Works through Europeana, Including Orphans?, Finnish Copyright Society Articles and Studies No. 2, Jan. 2013, at 9.

67. Register of Copyrights, supra note 3 , at 18.

68. Id.

69. Vuopala, supra note 66 , at 15.

70. Feliu, supra note 5, at 122-23. 
categories of works are to be used. ${ }^{71}$ Throughout the remainder of the Nordic countries, however, the available uses of works under the control of CMOs are typically limited to broadcasting and cable retransmission, reproductions for educational purposes, reproductions for internal use by businesses or similar organizations, and uses by libraries, museums, and archives. ${ }^{72}$ Essentially, this means that the Nordic ECL system facilitates uses, which may have a significant societal benefit, but may also carry high costs associated with obtaining permission for use on an individual basis. ${ }^{73}$ The limitation on what types of uses are covered by the ECL system is the extent of government involvement, as the CMOs and potential users are free to negotiate as they please within the parameters of the law. ${ }^{74}$ This arrangement serves to benefit both parties in that rights holders are granted assurances to the extent that their work will be used as well as receiving remuneration for such use, and users are able to proceed with their use of the work free from the threat of legal action by the rights holder or potential criminal sanctions. ${ }^{75}$

With respect to the mass digitization and online accessibility of the collections of various cultural institutions, the Nordic ECL system operates to limit the exclusive rights of authors for the benefit of such institutions as libraries and archives. ${ }^{76}$ Normally, all of the works in a specific digitization project are covered by the ECL system. ${ }^{77}$ When a project contains orphan works, they are always covered as well, because orphan works are treated in the same way as the other works in the project. ${ }^{78}$ Typically, European countries follow the European Commission's recommendation that orphan works not be included in ECL schemes unless a diligent search has been performed. ${ }^{79}$ However, the Nordic ECL system effectively eliminates this requirement for the potential user, as representative CMOs are entitled to enter into agreements with users allowing them to make use of all of a specific type represented work even if those works are orphans or the authors are not specifically represented by the CMO ${ }^{80}$ The costs of a diligent search, then, are shifted to the CMO, which is responsible for locating the rights holder in order to distribute any remuneration. ${ }^{81}$ If a rights holder of an orphan work included in an agreement discovers the use of his or her

71. Id

72. Register of Copyrights, supra note 3, at 18-19.

73. Id.

74. Id. at 19.

75. Vuopala, supra note 66, at 9.

76. Id. at 10 .

77. Id. at 11 .

78. Id.

79. Thomas Riis \& Jens Schovsbo, Extended Collective Licenses and the Nordic Experience: It's a Hybrid but is it a Volvo or a Lemon, 33 COLUM. J. L. AND ARTS 471, 479 (2010).

80. David R. Hansen, Kathryn Hashimoto, Gwen Hinze, Pamela Samuelson \& Jennifer M. Urban, Solving the Orphan Works Problem for the United States, 37 ColuM. J. L. \& ARTs 1, 46 (2013).

81. Id. 
work and wishes to withdraw it from the blanket license granted by the CMO, he or she is usually granted the right to do so via an opt-out clause in the statute. ${ }^{82}$

The Nordic ECL system has encountered a number of problems in adapting to the new digital environment, though ${ }^{83}$ Developed in the $1960 \mathrm{~s}$, the Nordic ECL system has traditionally only applied to secondary uses of works, such as photocopies of certain works to be used in schools and by businesses. ${ }^{84}$ Yet, the full range of secondary digital uses is impossible to identify at the outset of an agreement, which could potentially lead to disputes between authors and users. ${ }^{85}$ In the case of orphan works, licensing fees and other remuneration may be collected on behalf of the rights holders. ${ }^{86}$ However, if the rights holders cannot be located by the $\mathrm{CMO}$, there would be no one to whom to distribute the funds. ${ }^{87}$ Ensuring that CMOs are actually representative of a particular group of authors or rights holders has also been difficult to accomplish, as low interest in collective management of rights among authors in a certain category and fragmentation of larger groups of authors into smaller societies have hindered representativeness. ${ }^{88}$ For example, authors of theses and small leaflets or posters are not currently represented by any CMOs within the Nordic countries or even Europe as a whole, yet there has been interest in mass digitization and online access to such materials arising out of their utility to researchers. ${ }^{89}$ The lack of a representative CMO makes the formation of an agreement relating to the mass digitization of these works impossible under the Nordic ECL system, and the effort and cost required to individually license them is overly cumbersome or even impossible since many of these works are orphans. ${ }^{90}$ In addition, foreign rights holders, who are not typically members of CMOs located in the Nordic countries, have almost no way of knowing that their works are being used in those countries. ${ }^{91}$ Therefore, any funds accrued by the use of those works is likely to go unclaimed and be repurposed by the CMO managing the rights associated with the work. ${ }^{92}$ The result is that rights holders are deprived of funds that should rightfully be theirs. ${ }^{93}$ Thus, the Nordic ECL system continues to experience problems arising out of mass digitization and online accessibility efforts, which contain a substantial number of orphan works. ${ }^{94}$

82. Register of Copyrights, supra note 3 , at 49.

83. Vuopala, supra note 66, at 11.

84. Riis and Schovsbo, supra note 79, at 473-74.

85. Vuopala, supra note 66, at 11.

86. Register of Copyrights, supra note 3 , at 50.

87. Id.

88. Vuopala, supra note 66 , at 14.

89. Id. at 15.

90. Id.

91. Jonathan Band \& Brandon Butler, Some Cautionary Tales About Collective Licensing, 21 Мich. ST. J. INT’L L. 687, 698 (2013).

92. Id.

93. Id.

94. Vuopala, supra note 66 , at 15. 


\section{B. The Google Books and HathiTrust Cases in the U.S.}

\section{Google Books}

In 2004, Google announced it had entered into agreements with several major research libraries allowing Google to digitally copy books in the libraries' collections. ${ }^{95}$ These agreements brought into being the Google Books program, an undertaking by Google aimed at scanning more than twenty million books. ${ }^{96}$ Even though many of these books were under copyright protection, Google failed to acquire the necessary permission from the rights holders for its use of the books. ${ }^{97}$ As a result, shortly after the inception of the project, the Authors Guild filed a class action lawsuit against Google claiming that the project's creation of digital copies of copyrighted works constituted a massive copyright infringement. ${ }^{98}$ The Association of American Publishers followed suit nearly a month later, filing a similar claim against Google. ${ }^{99}$ In response, Google argued that by merely providing short snippets of works for which it was unable to secure the proper authorization, its use fell under the fair use exception. ${ }^{100}$ After nearly three years of litigation, the parties reached what they thought would be an acceptable settlement agreement. ${ }^{101}$ However, amid a litany of objections from not only various individual authors but also stakeholder groups and even foreign governments, they were forced to amend the settlement. ${ }^{102}$ The subsequent agreement still gave rise to a number of issues particularly regarding its treatment of orphan works. ${ }^{103}$ The amended settlement essentially proposed the creation of a CMO, referred to as an "Unclaimed Works Fiduciary." 104 This organization was intended to represent the interests of the rights holders of orphan works by setting prices, classifying books, and collecting and holding licensing fees for any rights holders who may be discovered later. ${ }^{105}$ Further objections on the part of the U.S. government and a number of foreign countries followed this announcement. ${ }^{106}$ Foreign objectors claimed the amended settlement would have violated various international agreements including the Berne Convention and the Agreement on

95. Authors Guild, Inc. v. Google Inc., 954 F.Supp. 2d 282, 284 (S.D.N.Y. 2013) [hereinafter "Google"].

96. Id. at $284-85$.

97. Id. at 284.

98. Lu, supra note 25 , at 262.

99. Id.

100. Id.

101. Register of Copyrights, supra note 3, at 14.

102. Id.

103. Lu, supra note 25, at 262.

104. Id.

105. Id.

106. Google, supra note 95, at 686. 
Trade-Related Aspects of Intellectual Property Rights (“TRIPS"). ${ }^{107}$ Certain foreign objectors also emphasized that the issue of orphan works was not limited to the U.S. but was a global problem. ${ }^{108}$ In particular, the government of France argued that because individual countries had begun implementing laws specifically dealing with the exploitation of orphan books in the digital age, it was each country, rather than a private entity, who should legitimately make such decisions regarding copyright law. ${ }^{109}$ The court ultimately concluded that the matter of how to handle the exploitation of orphan works was better left to Congress, stating, "the [settlement agreement] would also raise international concerns, and foreign countries, authors, and publishers have asserted that the [it] would violate international law."110

In October 2015, the Second Circuit Court of Appeals affirmed a district court ruling which held that Google's use of snippets of works for which it did not have the proper authorization to reproduce in full was indeed a fair use of the works protected by U.S. copyright law. ${ }^{11}$ The appellate judge noted that the snippets were short enough to provide sufficient protection to the original work such that the snippets would not act as market substitutes for the originals. ${ }^{112}$ Although the Second Circuit's decision appears to have ended what amounts to over a decade of litigation, the debate surrounding Google Books has by no means come to a close. ${ }^{113}$ The USCO has stated that the proposed settlement in the Google Books case can act as a template for any future ECL legislation in the U.S. ${ }^{114}$ The Book Rights Registry proposed by the settlement agreement would have acted as a CMO with similar rights and responsibilities as CMOs under the Nordic system, except that its approval would have been granted by a court rather than the government. ${ }^{115}$ An arrangement similar to the Google Books settlement may appear attractive to some, but others including the Authors Guild caution that legislation implementing an ECL framework should be more limited in scope. ${ }^{116}$ However, proponents of the Google Books settlement argue that limiting the scope of an ECL system to out-of-commerce books, for example, would lessen the educational value of the digital resources it is intended to provide. ${ }^{117}$

107. Id. at 684.
108. Id. at 685.
109. Id.
110. Id. at 678.
111. Alexandra Alter, Google's Digital Media Library Wins Court of Appeals Ruling, N.Y.
MES (Oct. 16, 2015), http://www.nytimes.com/2015/10/17/business/media/googles-digital-librarywins-court-of-appeals-ruling.html? $\mathrm{r}=0$ [https://perma.cc/DJ4L-7T89].

112. Id.

113. Stephen Heyman, Google Books: A Complex and Controversial Experiment, N.Y. TIMES (Oct. 28, 2015), http:/www.nytimes.com/2015/10/29/arts/international/google-books-a-complexand-controversial-experiment.html?_r=1 [https://perma.cc/JPYF5Q].

114. Register of Copyrights, supra note 3 , at 85.

115. Id. at $85-86$.

116. Id. at 86 .

117. Id. 
Another argument against the Google Books settlement, is that it would have provided Google with a revenue stream arising out of licensing fees for orphan works which the rights holders may never collect. ${ }^{118}$ This argument operates under the assumption that CMOs are motivated to extract as much revenue as possible from the public. ${ }^{119}$ Regardless of the beneficial goals of the Google Books settlement agreement and the potentially massive impact it could have on the future of orphan works and mass digitization legislation in the U.S., the agreement was rejected. ${ }^{120}$ Not only did the agreement potentially violate international treaties and agreements, but the court's rejection of the agreement also espoused concern that Google was not the most qualified entity to determine the course of U.S. copyright law due to its self-interest in the matter. ${ }^{121}$ Not only did the French Government share this sentiment, but the U.S. government in its Statement of Interest filed during the litigation did as well. ${ }^{122}$

\section{HathiTrust}

In September 2011, the Authors Guild again instituted litigation relating to the digital scanning and copying of books by Google, this time joined by two foreign authors' groups and several individual authors. ${ }^{123}$ The target of this litigation was HathiTrust, which is a group of colleges, universities, and other non-profit organizations that offers an extensive library of digitized copies of works taken from libraries around the world. ${ }^{124}$ HathiTrust was one of the organizations that entered into an agreement with Google allowing Google to make digital copies of its members' collections for Google Books. ${ }^{125}$ In exchange, the various colleges, universities, and non-profit organizations making up HathiTrust were provided with digital copies of all of the works in their collections ${ }^{126}$ HathiTrust then combined all of these digital copies into a database known as HathiTrust Digital Library, which is similar to Google Books. ${ }^{127}$ The HathiTrust Digital Library permitted all of its users to conduct full-text searches, allowed those with certified print disabilities to fully access the entire database, and created preservation copies of certain works most in need of such services. ${ }^{128}$ The Authors Guild sought to enjoin all of these uses by HathiTrust claiming that they violated the Copyright Act. ${ }^{129}$ In addition, the Authors Guild challenged the

118. Lang, supra note 1, at 123.

119. Id. at 122 .

120. Register of Copyrights, supra note 3 , at 15.

121. Id.

122. Id. at 14-15.

123. Lu, supra note 25 , at 262-63.

124. Id.

125. Authors Guild, Inc. v. Hathitrust, 902 F.Supp. 2d 445, 448 (S.D.N.Y. 2012).

126. Id.

127. Register of Copyrights, supra note 3, at 17.

128. Id.

129. Authors Guild, Inc. v. Hathitrust, supra note 125, at 449. 
University of Michigan's Orphan Works Project for the same reasons. ${ }^{130}$ The Orphan Works Project involved cooperation between HathiTrust and the University of Michigan in attempting to locate rights holders of works declared to be orphans. ${ }^{131}$ If a rights holder could not be located, the bibliographic information of the work would be posted on a website operated by HathiTrust for ninety days, and if the rights holder was not heard from a digital copy of the work became available for use by students, professors, and other authenticated users and visitors of the University of Michigan's library. ${ }^{132}$ The other institutions that made up HathiTrust eventually announced participation in this project as well, but at the outset of the HathiTrust litigation Michigan suspended the project indefinitely. ${ }^{133}$ As such, the district court judge declined to rule on the legality of the Orphan Works Project stating that because the project had been suspended, the crucial information relating to how the program would operate and whom it would affect were absent making any potential claims against the project speculative. ${ }^{134}$ As to the other claims against HathiTrust, the Court ruled that all of its uses were protected under fair use. ${ }^{135}$ On appeal, the Second Circuit upheld the district court's rulings that full text searches and full access to works for those with certified print disabilities were fair use as well as the decision that the claims relating to the Orphan Works project were not ripe for adjudication. ${ }^{136}$ However, the Court reversed the ruling that the creation of preservation copies was protected by the fair use doctrine. ${ }^{137}$

In early 2015, the Authors Guild dropped the case completely. ${ }^{138}$ Even so, the HathiTrust litigation remains a part of the discussion regarding mass digitization efforts and the need for legislation dealing with such efforts. ${ }^{139}$ The Hathitrust case raises a number of important issues, particularly relating to the utility of the fair use doctrine in resolving copyright disputes. While the district court judge focused his fair use analysis on what he described as HathiTrust Digital Library's "invaluable contribution to the progress of science and the cultivation of the arts," 140 the Second Circuit ruled that this consideration really has no place in the test of whether a use of a work is transformative, potentially entitling it to fair use protection. ${ }^{141}$ One of the arguments in the debate over legislation relating to

130. Register of Copyrights, supra note 3, at 17.

131. Authors Guild, Inc. v. Hathitrust, supra note 125, at 449.

132. Id.

133. Id.

134. Id. at 455-56.

135. Id. at 464 .

136. Register of Copyrights, supra note 3, at 18.

137. Id.

138. Andrew Albanese, Authors Guild Drops HathiTrust Case, Publishers Weekly(Jan. 8, 2015), http://www.publishersweekly.com/pw/by-topic/digital/copyright/article/65217-authorsguild-drops-hathitrust-case.html [https://perma.cc/J8JQ-9UCE].

139. See Register of Copyrights, supra note 3, at 13, 17-18.

140. Albanese, supra note 138.

141. Authors Guild, Inc. v. HathiTrust, supra note 125, at 464. 
orphan works and mass digitization is that the U.S. should do nothing and simply rely on fair use. ${ }^{142}$ However, courts such as the Second Circuit in the HathiTrust case have been unwilling to extend fair use beyond very narrow sets of circumstances. ${ }^{143}$ This seriously calls into question whether fair use can ever broadly grant groups wishing to undertake mass digitization efforts the use of a work's full text. ${ }^{144}$ Furthermore, the entire HathiTrust litigation declined to touch on the potential effect of fair use on orphan works, leaving that battle for another day. Consequently, fair use appears to lack the necessary force to effectively combat the orphan works and mass digitization problems.

\section{The Canadian Model}

The Canadian Copyright Act contains a provision allowing potential users of orphan works to apply to the Copyright Board of Canada for permission to use certain types of orphan works on a case-by-case basis. ${ }^{145}$ If the user is able to demonstrate that a reasonably diligent search for the rights holder took place and proved fruitless, the Board will grant the user a conditional nonexclusive license. ${ }^{146}$ The term "reasonable search" is not defined within the Act, so the Board is responsible for determining whether a search is reasonable. ${ }^{147}$ In order to prove that the user undertook a reasonable diligent search, he or she must outline every step he or she took in searching for the rights holder, file all documents relating to that search, and file an affidavit attesting to the search efforts. ${ }^{148}$ In addition to the information relating to the adequacy of the search for the rights holder, the Board has promulgated a set of informal standards for meeting the requirements for obtaining a license to use an orphan work. ${ }^{149}$ These standards include: whether the applicant is a commercial or non-commercial entity, whether the proposed use is for a commercial purpose, the nature of the work including the age of the work, and whether it contains any information about the author. ${ }^{150}$ Once a user has been deemed eligible to receive a license, the Board is required to set reasonable terms and conditions relating to that license including the amount to be paid by the user. ${ }^{151}$ The fee is then held for the rights holder, should he or she surface, for a period of five years, after which time the fee is distributed to the relevant copyright society (Canada's version of CMO's).${ }^{152}$ The licenses issued by the Board are conditional and non-exclusive,

142. Register of Copyrights, supra note 3 , at 5 .

143. Id.

144. Id.

145. Id. at 30 .

146. Id.

147. Feliu, supra note 5, at 128.

148. Lu, supra note 25, at 264-65.

149. Feliu, supra note 5, at 128.

150. Id.

151. Lu, supra note 25 , at 265 .

152. Id. at 265-66. 
and are typically only issued for published works and certain types of fixations. ${ }^{153}$ The law also currently provides for an exception for certain non-profit organizations that are acting on behalf of those with print disabilities. ${ }^{154}$ Canada's approach appears to be fairly popular around the world, as Japan, the United Kingdom, and China have either adopted or are considering adopting similar provisions. ${ }^{155}$

A number of key aspects of the Canadian governmental license system have been exposed as seriously flawed. ${ }^{156}$ The system continues to suffer from cumbersome administrative burdens, mostly arising out of the arduous task of operating on a case-by-case basis. ${ }^{157}$ Each search takes nearly two months on average, and as a result licenses are rarely issued. ${ }^{158}$ In fact, as of 2015, fewer than 300 licenses to use orphan works have been issued by the Board. ${ }^{159}$ Similar issues have plagued the Japanese system, which has seen fewer than 100 licenses issued in over forty years since the implementation of the governmental licensing system. ${ }^{160}$ It has been proposed that the government could retain the unclaimed licensing fees and apply them to administrative costs in an effort to ease the burden this program places on Canada's treasury, but this seems to be an improper course for a government to take. ${ }^{161}$ For that matter, the policy of allowing collective rights organizations to take the unclaimed fees after the fiveyear period has run has generated numerous complaints to the Board. ${ }^{162}$ Adding another wrinkle to these complaints are the allegations that collective rights organizations in Canada, such as Access Copyright, have been unfair in their distribution of funds to authors and publishers. ${ }^{163}$ Access Copyright is an organization which collects fees that go unclaimed past the five-year deadline for rights holders to claim them and has been notorious for its obscure financials. ${ }^{164}$ Eventually, it was discovered that less than ten percent of Access Copyright's revenue actually goes to the authors of the works it licenses out. ${ }^{165}$ Even though the Canadian Supreme Court effectively created a fair use right for educational institutions, Access Copyright has attempted to significantly increase the rates it charged for licenses and continued to aggressively pursue litigation aimed at limiting the effect of the fair use rulings. ${ }^{166}$ The ongoing Access Copyright saga

153. Register of Copyrights, supra note 3 , at 30.

154. Id. at 30-31.

155. Lu, supra note 25 , at 265-66.

156. Id. at 266 .

157. Id. at 266-67.

158. Id at 267.

159. Register of Copyrights, supra note 3 , at 31.

160. Id. at 32 .

161. Lu, supra note 25, at 266.

162. Id.

163. Band and Butler, supra note 91, at 694.

164. Id.

165. Id.

166. Id. at $723-724$. 
is indicative of many of the problems currently facing the Canadian system, including the need for greater transparency with regard to the use of the funds generated by licensing fees. ${ }^{167}$ In all, it makes sense that many have opposed granting the USCO authority, similar to that of the Copyright Board of Canada. ${ }^{168}$

\section{The EU's Approach}

In 2005, the EU began rolling out what it called its "i2010 Initiatives" aimed at addressing problems arising in the information society and media sectors. ${ }^{169}$ The next year, the European Commission issued a recommendation to member states that digitization should be used to preserve works and provide greater accessibility to them. ${ }^{170}$ Eventually, this led to the creation of Europeana, a centralized library created as part of the i2010 Digital Library Initiative. ${ }^{171}$ The principal purpose behind Europeana's creation was the preservation of Europe's cultural heritage and the provision of universal access to that heritage. ${ }^{172}$ Europeana was designed to cover all manner of cultural works including textual, visual, audiovisual, and sound recordings. ${ }^{173}$ Initially, Europeana did not include orphan works or works that were out of print for legal reasons. ${ }^{174}$ In response to this issue, the European Commission launched a public consultation on the future of the digitization of books in Europe. ${ }^{175}$

The European Commission issued a recommendation regarding orphan works in 2006, and this recommendation was focused on the digitization and online accessibility of cultural content as well as digital preservation of works. ${ }^{176}$ However, as this was only a recommendation from the Commission and thus carried little weight, only a few European countries bothered to enact orphan works legislation. ${ }^{177}$ By 2011, the Commission, in an effort to push countries that had yet to adopt any national orphan works legislation to do so, reworked its recommendation into a proposed directive aimed at ensuring uniform standards across Europe. ${ }^{178}$ This proposal was particularly concerned that the pending Google Books settlement, if accepted, would create a "knowledge gap" between

167. Lu, supra note 25, at 266.

168. Id. at 267.

169. Feliu, supra note 5, at 110.

170. Id.

171. Durantaye, supra note 20, at 244.

172. Id.

173. Id.

174. Press Release, European Commission, Europe's Digital Library Doubles in Size but Also Shows EU's Lack of Common Web Copyright Solution (Aug. 28, 2009), http://europa.eu/rapid/ press-release_IP-091257_en.htm?locale=en [https://perma.cc/UF2J-TDEX].

175. Id.

176. Lu, supra note 25 , at 270.

177. Id.

178. Id. at 271. 
the U.S. and Europe. ${ }^{179}$ The European Parliament and Council would eventually adopt the proposal and enact it as Directive 2012/28/EU ("Directive") dealing with certain types of uses of orphan works. ${ }^{180}$

In its introduction, the Directive notes the importance of mass digitization projects and notes the role that public libraries, educational institutions, museums, archives, and other similar organizations play in undertaking such projects. ${ }^{181}$ It states that the Directive has no effect on legislation recently enacted in member states that is aimed at providing a solution to the mass digitization issue as a whole. ${ }^{182}$ One of the main reasons behind the Directive's implementation is that because various countries across Europe had already been attempting to solve problems relating to orphan works using sometimes vastly different methods, access to orphan works across borders had become complicated. ${ }^{183}$ As such, the European Parliament believed that a uniform approach to the rules surrounding the use of orphan works was not only necessary, but it was best carried out at the Union level. ${ }^{184}$ It is noted, however, that the Directive only applies to works first published within the European Union in order to avoid any international conflicts, such as those exemplified in the attempted Google Books settlement. ${ }^{185}$

The Directive itself requires member states to enact legislation that brings each country's legal system into compliance with the articles of the Directive. ${ }^{186}$ Article 1 of the Directive limits its scope to books, journals, newspapers, magazines, other writings, and audiovisual works contained in the collections of libraries and other similar institutions and any public-service broadcasting audiovisual works published before January 1, 2003. ${ }^{187}$ Orphan works are defined in the Directive as those works for which either no rights holder is listed or no rights holder can be "located after a diligent search." 188 The diligent search requirement is seen to be the key element of any orphan works legislation and has been adopted by a number of different countries. ${ }^{189}$ For its part, the Directive allows each member state to consult with rights holders and users within that state in order to determine which sources must be searched before a search can be deemed diligent. ${ }^{190}$ Furthermore, the diligent search must begin in the state in which the work was first published or broadcasted. ${ }^{191}$ Beyond this, each member

179. Register of Copyrights, supra note 3, at 19-20.

180. Lu, supra note 25 , at 271.

181. Directive 2012/28/EU of the European Parliament and of the Council of 25 October 2012 on Certain Permitted Uses of Orphan Works $\$ 1$ (Eur.).

182. Id. at 94 .

183. Id. at $₫ \uparrow 8$.

184. Id. at $9 \uparrow 25$.

185. Id. at 9912 .

186. Id. at art. $9 \Upsilon 1$.

187. Id. at art. $1 \llbracket 2$.

188. Id. at art. $2 \uparrow 1$.

189. Lu, supra note 25, at 271.

190. Directive 2012/28/EU, supra note 181, at Art. 3 \2 (Eur.).

191. $I d$. at art. $3 \llbracket 3$. 
state is required to ensure that the public libraries and other similar institutions, which serve as the sources for diligent searches, maintain records of each search including: the results of the search, the uses made of the work for which the search was undertaken, any status changes for the work, and the relevant contact information for the source institution. ${ }^{192}$ All of the information is then to be stored in an online database that is accessible to the public and is managed by the EU's Office for Harmonization in the Internal Market ${ }^{193}$ Once a diligent search has been conducted and a work deemed orphan, that work's status as orphan will be recognized throughout the EU and may be accessed according to the Directive. ${ }^{194}$ The only permitted uses of the orphan works are providing access to the public and reproduction for the purpose of digitization, indexing, cataloging, preservation or restoration. ${ }^{195}$ In addition, the organizations making these uses are only permitted to do so in furtherance of a stated public interest mission. ${ }^{196}$ Each member state was supposed to have implemented the legislation conforming to the Directive by October 29, 2014. ${ }^{197}$ However, there was an exception for those countries that consider the implementation of the Directive to be a violation of already established management rights and have alerted the Commission thusly. ${ }^{198}$ As of June 2015, twenty member states had enacted the requisite legislation. ${ }^{199}$

The EU's approach to orphan works has been criticized for a number of reasons, the most prominent of which are its limited scope and failure to provide adequate certainty for potential users of orphan works. ${ }^{200}$ Both of these problems arise out of the fact that the Directive only applies to uses made by public libraries, educational institutions, museums, archives, and other similar organizations, thus leaving out the individual user. ${ }^{201}$ This has created issues of fairness in that organizations not engaged in carrying out public interest missions are excluded completely from the Directive. ${ }^{202}$ While early drafts of the Directive included a section allowing member states to issue specific licenses for the use of orphan works to organizations not undertaking public interest missions, this section was removed in the final draft. ${ }^{203}$ The failure to include such a section has handicapped the usefulness of the Directive by limiting the overall access to orphan works. ${ }^{204}$ These problems have led to very limited participation in

192. Id. at art. $3 ₫ 5$.

193. Id. at art. $3 \uparrow 6$.

194. Id. at art. 4.

195. Id. at art. $6 ₫ 1$.

196. $I d$. at art. $6 \uparrow 2$.

197. Id. at art. 991 .

198. Id. at art. 10.

199. Register of Copyrights, supra note 3, at 22.

200. Id. at 22 .

201. Lu, supra note 25, at 272 .

202. Id.

203. Id.

204. Id. 
Europeana as a whole. ${ }^{205}$ Furthermore, the Directive fails to touch on issues relating to who can authorize the use of orphan works, who can collect fees for such use and how those fees are to be used. ${ }^{206}$ This could be a result of the EU's unwillingness to include ECL as part of the Directive, although the EU has noted the importance of collective licensing as effective in the management of out-ofcommerce works. ${ }^{207}$ In the end, though, the Directive is far too limited in its scope, and leaves too many questions unanswered to provide an effective framework for solving the orphan works problem. ${ }^{208}$

\section{ARGUMENT}

\section{A. France's Law Regarding Out-of-Commerce Books}

In March of 2012, perhaps in response to the then-ongoing Google Books litigation, France passed a law aimed at allowing out-of-commerce books published in the 20th Century or earlier to be more easily digitized and made available to the public. ${ }^{209}$ This law covers all books published in France before January 1, 2001 that are not currently being distributed commercially. ${ }^{210}$ The law, known as Loi 2012/287, changed the French Intellectual Property Code by adding a chapter that provides for the following: the creation of an orphan works database, the designation of a CMO charged with the management and licensing of orphan works, the right of libraries to make orphan works available for free to their subscribers ten years after the first use, and the right of rights holders to opt out of the system. ${ }^{211}$ Orphan works are defined in the law as those works for which a rights holder cannot be located despite a diligent search. ${ }^{212}$ This does not include works with multiple rights holders if not all of the rights holders have been located but at least one has. ${ }^{213}$ The French Intellectual Property Code does not define "diligent search," however, it does note that the search must be proven

205. Durantaye, supra note 20, at 245.

206. Lu, supra note 25, at 273.

207. Register of Copyrights, supra note 3, at 22.

208. Lu, supra note 25, at 273.

209. Register of Copyrights, supra note 3 , at 25.

210. Id. at 25-26.

211. Marcela Favale, Fabian Homberg, Martin Kretschmer, Dinusha Mendis, and Davide Secchi, Copyright, and the Regulation of Orphan Works: A Comparative Review of Seven Jurisdictions and a Rights Clearance Simulation (2013) at 29, https://www.gov.uk/ government/uploads/system/uploads/attachment_data/file/312779/ipresearch-orphan-201307.pdf [https://perma.cc/5Y3G-VEMK].

212. Lucie Guibault, France Solves Its XXe Century Book Problem!, Kluwer Copyright Blog (Apr. 13, 2012), http://kluwercopyrightblog.com/2012/04/13/france-solves-its-xxe-century-bookproblem/ [https://perma.cc/XY4R-QMTA].

213. Loi 2012-287 du 1 mars 2012 relative à l'exploitation numérique des livres indisponibles du xxe siècle Art. 2 (2012), http://www.wipo.int/wipolex/en/text.jsp?file_id=273943 [https://perma.cc/N8R8-UW8N]. (Translated in Google Translate). 
and serious. ${ }^{214}$

The orphan works database is currently managed by the French National Library and allows anyone the opportunity to add a work to the database. ${ }^{215}$ Once a book has been registered on the database, the author or publisher of the book has six months to object in writing to the management of the work by the designated CMO or such management will commence. ${ }^{216}$ The designated CMO is La Société Française des intérêts des Auteurs l'écrit (French Society for the Interests of Print Authors - "SOFIA"), which is charged with investigating the possible rights holders of books that are claimed to be orphan works. ${ }^{217}$ If management of a book is not properly or timely objected to, SOFIA has the right to authorize or grant licenses to publishers wishing to exploit a book digitally. ${ }^{218}$ These licenses will be granted for a fee and will last for five years, at which point they are renewable by the publisher. ${ }^{219}$ If it is the publisher that objects to the exploitation of a book by SOFIA, the publisher must act to exploit the book within two years and bring proof of the effective exploitation of the book to SOFIA or the objection will be disregarded and SOFIA will maintain the right to exploit the book. ${ }^{220}$ Authors may still object to the exploitation of their work after the six-month period has lapsed on the basis of harm to their reputation or honor. ${ }^{221}$ The current list of unavailable books published by SOFIA contains over 174,000 titles published throughout the 20th Century. ${ }^{222}$

Loi 2012-287 has been criticized as an overextension of the Nordic ECL system in that it grants management authority exclusively to SOFIA, which did not have to prove that it was adequately representative of the relevant rights holders. ${ }^{223}$ Detractors have also criticized the opt-out provision on the law for its short timeframe for which rights holders have to object to collective management of their works and the provision that essentially forces publishers to exploit the book digitally within a short time or lose the right to do so. ${ }^{224}$ Those challenging

214. Code de la propriété intellectuelle, Art. 113-10 (2015), http://www.wipo. int/wipolex/en/text.jsp?file_id=363403 [https://perma.cc/HEN2-ADHJ]. (Translated in Google Translate).

215. Favale et al., supra note 211.

216. Loi 2012-287, supra note 213.

217. Feliu, supra note 5, at 123-24.

218. Loi 2012-287, supra note 213.

219. Id.

220. Id.

221. Jane C. Ginsburg, Fair Use for Free, or Permitted-but-Paid?, Columbia Law Sch. Ctr. for Econ. Studies, WORKING PAPER No. 481 at 41 (2014), http://poseidon01.ssrn. com/delivery.php?ID $=61800903112512208312210008009612412311701105201604209006410$ 50030101240690880020240920410390440520070310610950920300031251260130080530290 80082127092004002114016103071079015067071111106025108026020122096086104097000 $123083092011029110103087089119085092 \& \mathrm{EXT}=\mathrm{pdf}$ [https://perma.cc/4WTV-3SJY].

222. Liste de livres en gestion collective, supra note 52.

223. Register of Copyrights, supra note 3, at 27.

224. Ginsburg, supra note 221 , at 44. 
these provisions have claimed that they constitute a deprivation of the author's property by the government in violation of the French Constitution. ${ }^{225}$ The French government, however, has characterized the law as "a modern and efficient mechanism to regulate the use of unavailable works" and has claimed that France is the first country in the world to develop such a solution to the problems surrounding the digitization of its cultural heritage. ${ }^{226}$ Supporters also point out that the law provides a second life for long forgotten books that may be particularly valuable to researchers and historians, yet still manages to respect the main principles of copyright. ${ }^{227}$ The law has been seen as a solution to the problems associated with locating and assembling rights holders into a CMO while allowing books that may otherwise lie unused to earn revenue as well. ${ }^{228}$ Those responsible for introducing and defending the law believe that it does away with the issues of doubt surrounding the digital exploitation of orphan works and the unprofitability of out-of-commerce works. ${ }^{229}$ By combating both of those problems, the law allows orphan and out-of-commerce works to be converted to digital form, thus granting access to the works to everyone rather than those select few researchers who previously had access to the physical print version. ${ }^{230}$ It should also be noted that the type of mandatory collective management employed by Loi 2012-287 has been used in France before. ${ }^{231}$ For example, the rights of cable retransmission, public lending, and reproduction by reprography are managed by accredited CMOs bound by the good governance rules laid out in the French Intellectual Property Code much the same way SOFIA operates. ${ }^{232}$

Furthermore, in February of 2014, the French Constitutional Council, the highest constitutional authority in France, upheld Loi 2012-287 as consistent with the French constitution. ${ }^{233}$ In its decision, the Council noted that the contested provisions were aimed at furthering a public interest by allowing the public to

225. Conseil Constitutionnel, decision no. 2013-370 QPC, 28 février 2014, JORF du 2 mars 2014, 9 (Fr.), http://www.conseil-constitutionnel.fr/conseil-constitutionnel/francais/les-decisions/ acces-par-date/decisions-depuis-1959/2014/2013-370-qpc/decision-n-2013-370-qpc-du-28-fevrier2014.140194.html [https://perma.cc/HG3J-F9J3] (Translated in Google Translate).

226. Guibault, supra note 212.

227. Aurélie Champagne, Numérisation des livres qu'on n'édite plus: qui y gagne?, Rue89.com (Mar. 3, 2012), http://rue89.nouvelobs.com/rue89-culture/2012/03/03/numerisationdes-livres-quon-nedite-plus-qui-y-gagne-229855 [https://perma.cc/73MJ-8BBB].

228. Ginsburg, supra note 221 , at $44-45$.

229. Rapport $\mathrm{n}^{\circ} 151$ (2011-2012) de Mme Bariza Khiari, fait au nom de la commission de la culture, de l'éducation et de la communication, déposé le 30 novembre 2011. http://www.senat.fr/rap/111-151/111-1516.html\#toc79 [https://perma.cc/42CQ-G4AT]. (Translated in Google Translate).

230. Id.

231. Guibault, supra note 212.

232. Id.

233. French Constitutional Council Upholds French Law on Out of Print Books, IFFRO (Mar. 3, 2014), http://www.ifrro.org/content/french-constitutional-council-upholds-french-law-out-printbooks [https://perma.cc/W8VZ-XZJD] 
access previously unavailable books, while still employing a legally binding contract requiring those exploiting the books to offer fair remuneration to the rights holders. ${ }^{234}$ The Council stresses the fact that the books being exploited by the law are no longer commercially available and notes that despite the rather limited timeframe given for opposition, the law contains adequate safeguards for authors wishing to remove their works from SOFIA's control. ${ }^{235}$ The fact that the authors retain the rights to exploit their works in forms other than digital is another factor in the Council's decision to uphold the law. ${ }^{236}$ The Council takes into consideration the heavy emphasis on the right to own property expressed in the French constitution, but takes notice of the fact modern conceptions of "ownership" and "property" differ significantly from those held at the end of the 18th Century. ${ }^{237}$ As such, the Council was unable to hold that any right or freedom granted by the French constitution was violated or perverted in any way by Loi $2012-287.238$

\section{B. The U.S. Copyright Office's June 2015 Report}

Prior to 2015, the U.S. Copyright Office considered the issues of orphan works and mass digitization in two separate publications released in 2006 and 2011, both times noting the substantial impact these issues were having on the copyright system. ${ }^{239}$ In both of these previous reports, the USCO proposed a legislative solution, and both times nothing came to fruition. ${ }^{240}$ The 2006 report actually managed to spawn "two similar, but not identical" bills in the Senate and House. ${ }^{241}$ The proposed House bill, which failed to pass, included a broad definition of reasonable compensation as well as guidelines for a diligent search, the reasonableness of which would have to be determined by a court. ${ }^{242}$ The Senate bill, which passed in the Senate but failed in the House, expanded the definition of diligent search significantly and excluded explicit reference to judicial approval of the reasonableness of a search should a conflict arise. ${ }^{243}$ This, however, did not appear to be enough to assuage the fears of rights holders and potential users alike regarding the uncertainty of possible litigation arising from uses of orphan works. ${ }^{244}$ This uncertainty, in fact, had the potential of creating a

234. Conseil Constitutionnel, supra note 235, at $\$ 14$.Conseil Constitutionnel, decision no. 2013-370 QPC, 28 février 2014, JORF du 2 mars 2014, $\uparrow 14$, . (Translated in Google Translate)

235. Id. at $916-17$.

236. French Constitutional Council upholds French Law on out-of-print books, supra note 233.

237. Conseil Constitutionnel, supra note 234, at $\$ 12-13$.

238. Id. at $₫ 19$.

239. Register of Copyrights, supra note 3, at 1.

240. Id.

241. Feliu, supra note 5, at 120.

242. Orphan Works Act of 2008, H.R. 5889, $110^{\text {th }}$ Cong. (2008).

243. Shawn Bentley Orphan Works Act of 2008, S. 2913, $110^{\text {th }}$ Cong. (2008).

244. Ryan Andrews, Note, Contracting Out the Orphan Works Problem: How the Google 
chilling effect similar to that being caused by the current copyright regime, thereby leaving the U.S. with the same problem to solve. ${ }^{245}$

The USCO's June 2015 report takes into consideration all of these previous failures and seeks to provide solutions to the problems faced by individual users on a case-by-case basis. ${ }^{246}$ The most important of these issues is the chilling effect described above, which leaves potential users under a "legal cloud" regarding any uses of orphan works. ${ }^{247}$ This cloud has scared potential users of orphan works away from making use of these works at all, despite the strength of their position legally or the availability of fair use. ${ }^{248}$ This problem alone could severely hinder the fulfillment of the constitutional mandate to "promote the Progress of Science" through the copyright system. ${ }^{249}$ In addition to the chilling effect created by orphan works due to legal uncertainty, orphan works also have the potential to lead to excessively high costs for those undertaking mass digitization projects. ${ }^{250}$ Because such a project would require the persons undertaking it to seek permission from each individual rights holder, even if all of the relevant rights holders were easily located the costs to the users would far outweigh the utility of the project. ${ }^{251}$ Add to this the costs of diligently searching for those rights holders that are not easily located, and the project becomes an enormous waste of time and money. ${ }^{252}$

In an effort to combat these problems, the USCO has proposed a copyright regime modeled after an ECL system, which represents a significant departure from previous legislation based on limited liability. ${ }^{253}$ The recent rise of similar systems in places such as France, Germany, and the United Kingdom in order to combat issues surrounding mass digitization in particular was seen by the USCO as a significant factor in its choice to use ECL as the basis of its latest proposed legislation. ${ }^{254}$ Because ECL is such a significant departure from the U.S.'s current copyright regime, the USCO has proposed a limited "pilot program" focusing on three specific categories of works: (1) literary works, (2) pictorial or graphic works such as illustrations or diagrams, and (3) photographs. ${ }^{255}$ This framework would allow CMOs to be set up privately by relevant rights holders who would then be able to petition the USCO for permission to issue extended collective

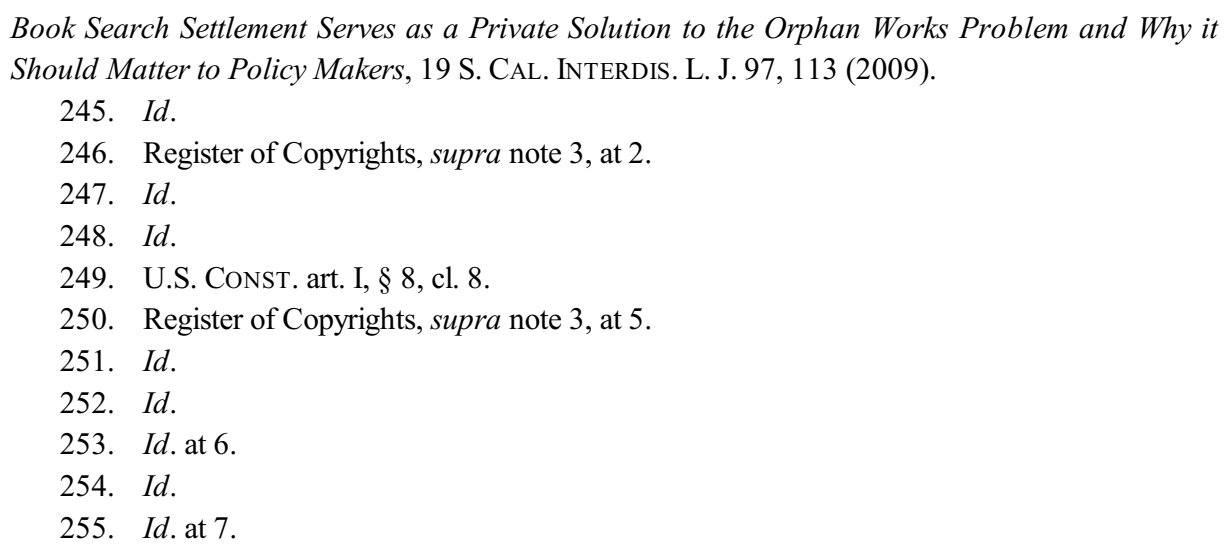


licenses in the relevant categories for certain mass digitization efforts. ${ }^{256}$ In order to receive approval from the USCO, a CMO would have to demonstrate that it represents a significant number of rights holders in that category of works and that a significant percentage of the members of that CMO have consented to ECL application. ${ }^{257}$

Recognizing the reasons for past failures to enact comprehensive orphan works legislation, the USCO provides in its 2015 report minimum standards to be adhered to in conducting a diligent search. ${ }^{258}$ These include searching the records of the USCO that are available to the public, searching sources of copyright authorship and ownership information, use of appropriate technology tools including internet databases whether free or paid, and any other actions that may be reasonable under the circumstances. ${ }^{259}$ In an effort to further reduce potential litigation costs, the USCO's proposed act provides that all licensing terms are to be freely negotiated, and should disputes arise, any of the parties may elect a statutory licensing scheme with the rates set by the Copyright Royalty Board. ${ }^{260}$ It should be noted that this aspect of the system could lead any of the parties involved in the negotiations to forgo good faith negotiations in lieu of the statutory scheme should they believe such a scheme would be more beneficial to them. ${ }^{261}$ However, allowing the Copyright Royalty Board to act as an arbitrator rather than simply setting the licensing scheme on which the parties may fall back could solve any of these issues. ${ }^{262}$ Finally, the USCO made it a point to note that a straightforward opt-out provision is an essential element of any orphan works legislation. ${ }^{263}$ The USCO believes that such a provision must allow a rights holder adequate opportunity to opt out of the collective licensing of his or her work before and after licenses have been issued. ${ }^{264}$ Any such provision must also prescribe a reasonable time period within which CMOs must respond to opt out requests as well as terminate licenses if they have already been issued. ${ }^{265} \mathrm{In}$ all, the USCO's proposal is driven by the need to create more opportunities to spread creativity and knowledge. ${ }^{266}$ In addition, the USCO espouses the goals of legal certainty for both users and rights holders as well as providing a means of compensation to rights holders of works lying dormant or unused. ${ }^{267}$ While the USCO's proposed legislation does much to further these goals, it is little more than a proposal and will likely undergo significant changes should it be

256. Id.

257. Id.

258. Id. at 5.

259. Id. at app. A p. 3.

260. Id. at 96 .

261. Ginsburg, supra note 221, at 55.

262. Id.

263. Register of Copyrights, supra note 3, at 93.

264. Id.

265. Id.

266. Id. at 105.

267. Id. at 106. 
introduced to Congress as a potential law.

\section{How France's Law Fits with the USCO's Proposal}

While a number of key differences in the U.S. and French copyright regimes prevent directly copying and pasting France's law regarding out-of-commerce books into the USCO's proposed legislation, the basic goals of both copyright systems could allow a law similar to France's to be implemented in the U.S. Perhaps the biggest difference between the copyright regimes of the U.S. and France is the presence in the U.S. of fair use, of which the Ninth Circuit recently stated, "is not just excused by the law, it is wholly authorized by the law."268 Previously, fair use had been described as a defense to copyright infringement, but this decision, as yet unchallenged, paints fair use as a basic right of U.S. citizens rather than a defense. Indeed, fair use as it exists in the U.S. is a uniquely American right. As such, the USCO was keen to include a fair use savings clause in its proposed legislation, which states that nothing in the law will act to limit or destroy the application of fair use. ${ }^{269}$ However, the USCO also notes that in the case of mass digitization of entire literary works, fair use is unlikely to have any substantial effect. ${ }^{270}$ Another key difference between the USCO's proposal and the French approach to copyright law is France's apparent lack of clarity regarding what constitutes a diligent search. Although the French Constitutional Council declared that France's law is in no way unintelligible, ${ }^{271}$ France has, as of 2015, adopted the European Union's Orphan Works Directive, which includes certain requirements for a diligent search. ${ }^{272}$ As such, a diligent search in France must now include searching through relevant sources as determined by rights holders and users in the state in which the work originated, as well as the databases of public libraries and similar institutions. ${ }^{273}$ In addition, France will be responsible for maintaining accurate records of previous search results and up-todate contact information for rights holders, all of which will be held in a database

268. Lenz v. Universal Music Corp., 801 F.3d 1126, 1132 ( $9^{\text {th }}$ Cir. 2015) (describing fair use by quoting 17 U.S.C. 107: "Notwithstanding the provisions of sections 106 and 106A, the fair use of a copyrighted work, . . . for purposes such as criticism, comment, news reporting, teaching (including multiple copies for classroom use), scholarship, or research, is not an infringement of copyright").

269. Register of Copyrights, supra note 3 , at 101.

270. Id.

271. Conseil Constitutionnel, supra note 234 , at 919.

272. See Loi 2015-195 du 20 février 2015 portant diverses dispositions d'adaptation au droit de l'Union européenne dans les domaines de la propriété littéraire et artistique et du patrimoine culturel, tit. II art. 4, (2015), http:/www.legifrance.gouv.fr/affichLoiPreparation.do;jsessionid= 36DC25E5A3C56728ACC6DD2D5C709138.tpdjo14v_2?idDocument=JORFDOLE000029620 $502 \&$ type $=$ contenu $\&$ id $=2 \&$ typeLoi $=$ proj\&legislature $=14 . \quad$ (Translated in Google Translate) [https://perma.cc/PYA8-RF93].

273. Directive 2012/28/EU, supra note 181, at art. 3 qๆ 2-3, 5. 
accessible to the public that also acts as a source used in a diligent search. ${ }^{274}$ These provisions, now law in France, closely mirror several provisions in the USCO's proposed legislation including the requirement that appropriate databases and other relevant sources of contact information be consulted, as well as the requirement that the USCO maintain an up-to-date list of recommended search practices based on previous searches and comments. ${ }^{275}$

Negligible differences aside, the reasoning behind a push to craft a solution to the orphan works problem in France as well as the U.S. appears to be the same. In its 2015 report, the USCO acknowledged the need to balance the potential "valuable informational or educational purposes" served by allowing digital access to orphan works against "the potential harm to a copyright owner's legal rights and economic investments." ${ }^{.276}$ Likewise, in its decision to uphold France's Loi 2012-287, the French Constitutional Council noted that the contested provisions of the law not only covered a general interest of the state but also provided adequate safeguards for rights holders, such that the collective management and digitization of their works could not be considered a deprivation of their rights. ${ }^{277}$ In addition to motivational similarities, the French Intellectual Property Code shares several important provisions with the USCO's proposal. Perhaps the most obvious is the use of an ECL framework as the basis of both schemes. France's version is slightly different in that it includes mandatory collective licensing to be undertaken by SOFIA, which was not required to show that it was representative of a significant number of rights holders in the field of literary works. ${ }^{278}$ On the other hand, the USCO's proposal explicitly requires that CMOs be deemed representative of a significant number of rights holders in whatever field they will be operating. ${ }^{279}$ However, both systems emphasize the need for government oversight of the CMOs. In France, this takes the form of binding SOFIA to the rules for good governance laid out in the French Intellectual Property Code ${ }^{280}$ while in the USCO's proposal this oversight is accomplished by the requirement that CMOs request permission to engage in collective licensing from the USCO itself. ${ }^{281}$ Both France and the U.S. have acknowledged the necessity of adequate opt-out provisions, as well. France's Loi 2012-287 provides that an author may unconditionally opt out of SOFIA's management of the rights associated with his or her work within six months. ${ }^{282}$ The law further provides that an author and publisher acting jointly, or an author claiming harm to his or her reputation or honor may opt out at any point even if

274. Id. at art. 3 qा 5-6.

275. Register of Copyrights, supra note 3, at app. A p. 3-4.

276. Id. at 5 .

277. Conseil Constitutionnel, supra note 234, at $\uparrow \uparrow 14,18$.

278. Register of Copyrights, supra note 3, at 27.

279. Id. at 7.

280. Guibault, supra note 212.

281. Register of Copyrights, supra note 3, at 7.

282. Loi 2012-287, supra note 213. 
collective management has commenced. ${ }^{283}$ The USCO's proposal does not give as detailed a description of a potential opt-out provision as the one provided in Loi 2012-287, but it does note the importance of allowing rights holders the opportunity to opt out of collective management before and after such management has begun. ${ }^{284}$

The USCO appears to scoff at the idea of adopting a law similar to Loi 2012287 , because the presence of the use-it-or-lose-it provision requiring publishers to exploit the book within a certain time period or lose the right to another publisher may render the opt-out provision ineffectual. ${ }^{285}$ However, the fact that the French Constitutional Council found that the law passed constitutional muster in France should provide a strong indication of the law's viability in the U.S. Whether the USCO was aware of the Constitutional Council's decision at the time of the release of its report and proposal is unclear, but a number of reasons exist as to why that decision should hold some weight in the U.S.

As an initial matter, the basic idea of property as an inviolable right of man is one of the foundations of the governments of both countries. France's 1789 Declaration of the Rights of Man states, "[s]ince property is an inviolable and sacred right, no one shall be deprived thereof except where public necessity, legally determined, shall clearly demand it, and then only on condition that the owner shall have been previously and equitably indemnified."286 Similarly, the Bill of Rights in the U.S. Constitution ratified in 1791 provides that no person will "be deprived of life liberty or property without due process of law; nor shall private property be taken for public use, without just compensation." 287 This similarity is no mere coincidence, as the architects of the Declaration of the Rights of Man, Joseph-Emmanuel Sieyès and the Marquis de Lafayette, were both heavily influenced by the leading political minds of U.S. at that time. ${ }^{288} \mathrm{In}$ fact, in writing the original version of the Declaration of the Rights of Man, Lafayette consulted directly with Thomas Jefferson, the author of the American Declaration of Independence. ${ }^{289}$ Even though both documents were written well over 200 years ago, both continue to serve as the basis for the law of property in each document's respective country. ${ }^{290}$ In addition to the historic connection of the founding of the French and American governments and the constitutional similarities, the French Constitutional Council's decision to uphold Loi 2012-287 includes an analysis eerily similar to the strict scrutiny review employed by the

283. Conseil Constitutionnel, supra note 234 , at $₫ 17$.

284. Register of Copyrights, supra note 3, at 93.

285. Id. at 27 .

286. Declaration of the Rights of Man Aug. 26, 1789, art. 17 (Fr.), available at http://avalon.law.yale.edu/18th_century/rightsof.asp [https://perma.cc/ET3V-R4M9].

287. U.S. Const. amend. V.

288. Gregory Fremont-Barnes, Encyclopedia of the Age of Political Revolutions and New Ideologies, 1760-1815 190 (Greenwood Pub. Group, 2007).

289. Id.

290. See Conseil Constitutionnel, supra note 234, at $₫ 12$. and Golan v. Holder, 132 S. Ct. 873, 892 n. 33 (U.S. 2012). 
Supreme Court in cases involving potential infringement on fundamental rights. The strict scrutiny standard requires that laws infringing on fundamental rights be narrowly tailored to further a substantial government interest. ${ }^{291}$ To that end, the French Constitutional Council first notes that the right to own property is a basic right in France and even goes so far as to quote the Declaration of the Rights of Man. ${ }^{292}$ The Council also notes that the law is narrowly tailored to only affect the rights of authors with respect to the digitization of their work and goes on to declare that the law does not disproportionally interfere with the rights holder's property rights when compared against the objectives pursued by the law. ${ }^{293}$ Of course, the strict scrutiny standard has not been applied to cases involving government takings in the U.S. The Supreme Court has somewhat controversially favored a more lenient standard and acknowledged that when the purpose of a taking is the future use of the property by the public, the state is justified in transferring property from one private party to another. ${ }^{294}$ While that decision dealt with real property and has been criticized by many, it appears to be dealing with at least a similar issue to the one raised by the use-it-or-lose-it provision in Loi 2012-287. To that effect, the French Constitutional Council noted that that provision "does not result in deprivation of property within the meaning of Article 17 of the [Declaration of the Rights of Man]."295

All of this points to the viability and constitutionality in the U.S. of a law similar to France's. If adopted, such a law would have the potential to streamline the process of allowing the public to access works that have gone unused for years in furtherance of educational and artistic endeavors. Additionally, it would still provide rights holders the opportunity to opt out of any such uses should they so wish, or to earn some sort of financial compensation on a work that otherwise likely would have disappeared. Indeed, District Judge Denny Chin listed all of these benefits in his decision in favor of Google Books and concluded that "all society benefits" from the Google Books project. ${ }^{296}$ Loi 2012-287 was specifically designed to address the problems faced by Google Books - many of which it still faces even after its limited victory in court — and facilitates access to the entire work rather than only a small part of it, as Google currently allows for books to which it does not have full rights. ${ }^{297}$ Thus, the French law attempts to provide for the very same benefits Judge Chin lists for Google Books while addressing the shortcomings that may act to limit the impact of those benefits.

291. See Planned Parenthood v. Casey, 505 U.S. 833, 871 (U.S. 1992).

292. Conseil Constitutionnel, supra note 235 , at $₫ 12$.

293. Id. at $9 \uparrow 15,18$.

294. Kelo v. City of New London, 545 U.S. 469, 477 (U.S. 2005).

295. Conseil Constitutionnel, supra note 234, at 918.

296. Dimitra Kessenides, Judge Says 'All Society Benefits' From Google Books, BloomberG BusINESS (Nov. 14, 2013), http://www.bloomberg.com/bw/articles/2013-11-14/judge-says-allsociety-benefits-from-google-books [https://perma.cc/4ZQ2-K6YR].

297. Rapport $\mathrm{n}^{\circ} 151$, supra note 229. 


\section{CONCLUSION}

The debate on exactly how to craft a legislative solution to the orphan works and mass digitization problems in the U.S. is ongoing. As is the case in other jurisdictions attempting to enact orphan works legislation, those in the creative community have been hesitant to support collective rights management. ${ }^{298}$ Indeed, the USCO's most recent proposal has prompted such responses, even spawning an online petition referring to the proposed legislation as a "license to steal" bill. ${ }^{299}$ Others have criticized the USCO for downplaying the effectiveness of fair use as a mechanism for granting access to orphan works to those wishing to make use of them. ${ }^{300}$ Those in support of the USCO's proposal believe that the proposed legislation can have the desired effect of facilitating more extensive use of orphan works by making it less dangerous to take a chance on using such a work. ${ }^{301}$ Recognizing that the state of U.S. copyright law is very much in flux even after releasing its most recent proposal, the USCO is still seeking input from those potentially affected by the proposed legislation. ${ }^{302}$ Given the continued debate and the fact that the USCO has released previous proposals with no legislation passed, it stands to reason that the USCO's current proposal will not pass without significant changes.

Clearly, France and the U.S. share common values with respect to the importance of protection of copyright holders. On the other hand, both countries recognize the potential value of the mass digitization of orphan works. As discussed previously, France's law regarding out-of-commerce books has much in common with the proposal made by the USCO. However, France's law is very limited in scope, whereas the USCO's proposal is much more comprehensive. Despite the differences, the policy considerations behind both are in harmony with each other, and the USCO's proposed legislation is just that: a proposal. The USCO recognizes that its proposal will likely undergo various changes on its way to potentially becoming law in the U.S., and a provision similar to France's outof-commerce books law could easily be blended with the USCO's proposed legislation. Even if such a provision is limited only to books, it could go a long way to solving the problems exemplified in the Google Books and HathiTrust cases, which have only recently been fully resolved, still leaving numerous questions concerning the future of orphan works and mass digitization in the U.S.

298. Michael Zhang, Orphan Works Copyright Law Being Considered Again in the US, PETAPIXEL (Jul. 21, 2015), http://petapixel.com/2015/07/21/orphan-works-copyright-law-beingconsidered-again-in-the-us/ [https://perma.cc/E7C3-ZN86].

299. Id.

300. Krista Cox, Copyright Office Releases Report on Orphan Works and Mass Digitization; Recommends Burdensome Legislation, InfoJustice.org (June 8, 2015), http://infojustice.org/archives/34547 [https://perma.cc/A52H-WA44].

301. Maira Sutton, Users to USTR: Don't Sign Away Our Ability to Fix the Orphan Works Problem, eff.org (Aug. 31, 2015), https://www.eff.org/deeplinks/2015/08/users-ustr-dont-signaway-our-ability-fix-orphan-works-problem [https://perma.cc/76J3-E8AK].

302. Michael Zhang, supra note 298. 
If allowing the public access to orphan works truly will provide academic and artistic benefits, the U.S. must find a way to resolve any copyright issues expediently. France's law does just this, and the French Constitutional Council has held that it also provides adequate safeguards to copyright owners. These considerations and the fact that both France and the U.S. are constrained by the principles of the Berne Convention as well as a common reverence for the importance of property rights should at least allow France's law on out-ofcommerce books to be a part of the unavoidable debate over how to structure an orphan works regime in the U.S. 